\title{
CONTEMPORARY ADAPTATIONS OF KING LEAR: POWER AND DRAMATIC SPACE IN WILLIAM SHAKESPEARE, EDWARD BOND AND ELAINE FEINSTEIN
}

ADAPTACIONES CONTEMPORÁNEAS DE EL REY LEAR: PODER Y ESPACIO DRAMÁTICO EN WILLIAM SHAKESPEARE, EDWARD BOND Y ELAINE FEINSTEIN

\author{
Ana Abril Hernández \\ Independent scholar \\ ana.ab.her@gmail.com
}

\begin{abstract}
In his tragedy King Lear (1605) William Shakespeare explores the human psyche through a story of an old king who gives up his land to his two eldest daughters and finds himself forced to wander in the space of the outcasts. In his modern version of this play entitled: Lear, Edward Bond resumes Shakespeare's analysis of space and power in the figure of a monomaniac father who raises a wall against his enemies. The division of inner-outer spaces present in Bond is further explored in Elaine Feinstein's and the Women Theatre Group's work: Lear's Daughters, which immerses the audience into the early years of Goneril, Regan and Cordelia. In this contemporary prequel to Shakespeare's play the three princesses discover the world and the space they occupy in it from their seclusion in the castle.
\end{abstract}

Keywords: Shakespeare, King Lear, Edward Bond, Elaine Feinstein, space, drama.

\section{Resumen}

En la obra El rey Lear (1605), William Shakespeare explora la psique humana a través de la historia de un anciano rey que cede su tierra a sus dos hijas mayores y se ve obligado a vagar por el espacio de los marginados. En la versión moderna de esta obra titulada: Lear, Edward Bond retoma el análisis de Shakespeare del espacio y el poder en la figura de un padre monomaníaco que levanta un muro contra sus enemigos. La división de los espacios internos y externos presentes en Bond se explora más a fondo en el trabajo de Elaine Feinstein y del Women Theatre Group: Lear's Daughters, que sumerge al público en los primeros años de Goneril, Regan y Cordelia. En esta precuela contemporánea de la obra de 
Shakespeare, las tres princesas descubren el mundo y el espacio que ocupan en él desde su reclusión en el castillo.

Palabras clave: Shakespeare, King Lear, Edward Bond, Elaine Feinstein, espacio, teatro.

\section{Introduction: Lear, space and power through time}

As the Polish scholar Jan Kott claims in: Shakespeare our Contemporary: "King Lear is a play about the disintegration of the world. [...] Until it falls it has to exist, it has to exist with its hierarchy of power, with its faiths, rituals, and ceremonies, with its mutually entangled relationships of power" (364-65). In his words lies the key to the understanding of the theatricalization of spaces of power in Shakespeare's tragedy: King Lear (1605). The use of spaces in this play hints at a derelict world. The modern revisions of this king discussed hereafter study the hierarchies of power embedded in the use of space and its connection with the figure of this character, the natural man. The Shakespearian canon tends towards the dichotomy: body-soul as Harold Bloom notes (26) where nature occupies the space of the material. Therefore, exploring King Lear regarding the natural spaces in this play helps to understand power relations and hierarchies and how they change in this story. The father of English drama was rather pessimistic about the world, with Lear suffering the consequences of the division of his kingdom among his daughters, he would be forced to become familiar with the life of the outcasts. The critical reception of this play has moved from the study of space to the subjectivity of characters to understand better their motivations and actions, as Andrew Bozio states (100).

This king's fateful fall is imitated in Edward Bond's (1934-present) theatrical adaptation: Lear (1971), where the author transforms the spaces of power such as the royal castle into a nightmarish fortress. This mechanism aims at perpetuating the tyrannical power that passes from hand to hand symbolized by the wall he raises to "be free" (Bond 3). Spaces of power are at the service of those who take the throne, be it Lear, his daughters, or the morphed character of Cordelia in Bond's adaptation. Elaine Feinstein (1930-present) and the Women Theatre Group (WTG) offer a prequel to King Lear entitled Lear's Daughters (1987) that "asks us to consider narrative alternatives that disrupt the sedimentation of convention gathered around its source" (Fischlin and Fortier 216) by revealing the origin of the two formerly cruel sisters, Goneril and Regan. These women are now shown in their earliest years alongside the youngest, Cordelia. The setting in Feinstein's play is announced by the Fool (a hybrid figure who plays the part of 
the Fool, the King and the Queen) and it is: "[t]hree sisters, playing in the nursery, with the mother who sells [their nurse], but not the mother who buys [the Queen]" (222).

The performative potential of geographical spaces onstage that King Lear entails with his map was a major dramatic innovation in his time. As examined below, this map is a cartographic rendering of the territory that represents his power materialized in the land he owns. Yet, Lear's control of his territory is not as solid as he thinks according to Henry S. Turner since the king makes reference to the map as being vaguely "there" and not reaching out to it (Turner 171). This map $^{1}$ is only one manifestation of the potential power of space at stake in King Lear. Power changes hands in detriment of Lear's possessions and of his value as a king. Bond's and Feinstein's plays perform onstage the same power dynamics than Shakespeare with space thus adopting different meanings and attesting the organic nature of human relations with regard the space they occupy in a certain moment, which constitutes the basis of the hierarchy of power as noted by Kott (364-65). The correlation between the external history-i.e., objective passing of time - is always ahead of humans' actions in it - i.e., the lives of the individuals , as Joyce Carol Oates states (20).

The woods (and all of nature, by extension) become, therefore, the new home for the rejected king. In the same manner, the wall that symbolizes power in Bond's Lear corrupts every new ruler and the palace where the young princesses gather in Lear's Daughters serves as the only anchor to the present while they keep calling on the past perpetually. The Spanish critic Candelaria Vizcaíno Macero calls them: "spaces of power" and defines them as: "those places, in those chronotopes that, in one way or another, direct us to the temporal and, above all, spatial materialization of power and, especially, of political power" (italics in the original; my translation; 440). Although thorough in approaching the role of space in King Lear in rapport with power, Vizcaíno Macero's use of the Bakhtinian notion of the chronotope draws on the structuralist approach to text analysis. The present article complements the interpretation of spaces in Shakespeare's play by extending it to two modern pieces of drama based on King Lear, which draw on poststructuralist theories of analysis of space in theatre such as those put forth by Michel Foucault, Henri Lefebvre and Michel De Certeau.

\footnotetext{
${ }^{1}$ For a study of Lear's map in Shakespeare as an object and a symbol, see John Gillies, "The Scene of Cartography in King Lear" where this scholar explores Lear's map (Gillies 109).
} 


\section{From kings to outcasts: new venues of power}

One of Shakespeare's most admirable literary exploits in King Lear is the creation of quasi-magical spaces in this tragedy so much so that Frye refers to it as: "the spookiest of all the great tragedies" (107) but in spite of this atmosphere "nothing explicitly supernatural or superhuman occurs in in" (107). The spaces are materialized in Kent's prophetical statement after Lear banishes him from his land upon defending Cordelia's love for her father: "[f]are thee well, king. Sith thus thou wilt appear, / Freedom lives hence, and banishment is here" (Shakespeare, I.i. 204-205). Kent's statement anticipates the basis for the understanding of spaces outside the walls of the royal castle: the spaces of the "Other". Geographical settings are given and received so that social norms are inherently biased, equating civilization with reason and the wilder nature with "the realm of brutishness, of animals and roots, of standing pools and naked madmen" (Sewell 307). However, it will be amidst that wilderness that Lear's epiphanic revelation occurs ironically enough only when he goes mad. The turning point in Shakespeare's tragedy is the storm scene, where the storm not only represents the king's escalation to madness (Bloom 258) but also the Fool's awareness of their actual situation as outcasts (Shakespeare, III.ii. 16-26). In Lear's cursing of the storm and filial ingratitude, his discourse reaches its peak when he claims that he never "gave kingdom" (Shakespeare, III.ii. 19) to the storm. In that moment he is referring in spatial terms to mechanism of power holding (i.e., the kingdom). It is then that the pitiful king laments his losing his power as he lost his place in society.

Lear's initial misapprehension of Cordelia's affection for him leads him to make his fatal mistake and become himself one of the "Others," along with the Fool and Kent. His anagnorisis comes too late and he, at first, refuses to let madness take control of him: "[i]n resisting and banishing the 'Other,' that part of the soul that is highest in man, Lear exaggerates man's natural tendencies to resist his own fulfillment, just as this tragic work exaggerates the literal dangers of such resistance" (Oates 28). Bond shows them as spaces of madness which eventually collide with a violent reality rendering the boundaries between power and the subjugated (outcasts and the Fool and later on, Lear too) more ambiguous in his adaptation: Lear. Bond's play turns spaces inside out from a gender perspective where the exterior of the castle is evoked by the memories of the actresses with occasional references to life beyond the borders of the castle: "[w]e had to build a bridge to get to him. The Queen crossed the bridge and everybody had to cheer" (Feinstein 223).

In his book: The Production of Space the French philosopher and sociologist Henri Lefebvre delves into a trialectics of space where he defines representational spaces as bearers of "complex symbolisms, sometimes coded, sometimes not, 
linked to the clandestine or underground side of social life" (33). The clandestine and underground aspect is akin to the space occupied by social outcasts, who belong to the homogenized category known as the "Other;" that which is not me. ${ }^{2}$ Shakespeare has the group of the heath dwellers be outcasts, only accepted in the symbolic space of nature. Therefore, nature in Shakespeare's King Lear, contrary to Lear's expectations become a shelter for the old king rejected by his rapacious daughters Goneril and Regan. In his book The Wheel of Fire, George Richard Wilson Knight draws attention to the abundant references in King Lear to the natural landscape in close connection with the king. Knight identifies this natural setting as his real home, not a temporary one: "[ $\mathrm{t}]$ he world of King Lear is townless. It is a world of flowers, rough country, tempestuous wind, and wild, or farmyard, beasts; and, as a background, there is continual mention of homely, countrified customs, legends, rhymes" (180). This natural landscape provides the cure for his metaphoric blindness and his awareness-raising ordeal (Vizcaíno Macero 454). ${ }^{3}$ The storm that lightens up the darkness of the night when Lear intends to wander moves Kent to offer the king the protecting shelter of a hut:

Alack,

bareheaded?

Gracious my lord, hard by here is a hovel.

Some friendship will it lend you 'gainst the tempest.

Repose you there while I to this hard house-

More harder than the stones whereof 'tis raised,

Which even but now, demanding after you,

Denied me to come in-return and force

Their scanted courtesy. (Shakespeare, III.ii. 64-72)

The magnificent castle that Lear once inhabited with his three daughters and which symbolized power is now seen as a "hard house" since it has become the source of grief of its former owner and has morphed into a dwelling "harder than the stones whereof 'tis raised." Just as “[t]he tyranny of this open night's too rough / For nature to endure" (III.iv. 2-3) mirrors the internal turmoil that Lear is suffering cathartically prior to his fatal ending. If Lear, Kent and the Fool are "minded like

\footnotetext{
${ }^{2}$ In her article, Vizcaíno Macero examines the version of King Lear directed by A. Kurosawa titled Ran in which this critic explores the subject of the characters' struggle for self-identity regarding the "Other" (448-50).

${ }^{3}$ As Bloom has it, Lear's mind is as obscure to us as it was for himself prior to his descent into madness (482) with this king being depicted as a sort of fallen god partly akin to Bond's Lear.
} 
the weather, most unquietly" (III.i. 2) it is because they now belong in nature, the inside-outside frontiers have disappeared. In fact, they never return to the so-called civilized world they left. In some of Shakespeare's plays, the heaths are a realm inhabited by magical beings ${ }^{4}$ (as in A Midsummer Night's Dream) or the deathbed of courtly love (as for Ophelia in Hamlet). In King Lear the forest is home for Lear and the Fool, "strangers [who] continually meet" (Barton 96) in the midst of great turmoil with the forest being "alien and "other" (Barton 95) while simultaneously representing not only a part of nature but a much more extensive and unprecise space, as Henry S. Turner agrees (161).

Lear rewards love - or rather, the fallacious expression of filial love - with the most material of goods: his land. Lear takes this to the extent that he calls for a map to express the esteem owed by each daughter to him in spatial terms: "[m]eantime we shall express our darker purpose. / Give me the map there" (I.i. 37-38) since the map "confirms the royal power to administrate and allocate space" (Turner 171). His self-deceitful will to be praised leads him to be deprived of his house, his goods and his kinship. He is forced to live alienated from a society that was not only his own but which he ruled over in a self-triggered fall from grace. Outside the safe walls of his castle life is an incessant buzzing of dangers that Bond accentuates in his version of this story with all sorts of crimes of the vilest type including torture, murder and rape. Once he becomes a peer to the Fool in the woods Lear chooses life in the outside before asking his daughters for mercy; he gives up his power as a king in favor of his morality as a human being ("Rather I abjure all roofs, and choose / To wage against the enmity o' th' air, / To be a comrade with the wolf and owl" [II.iv. 240-242]), a lesson that his elder two daughters did not follow.

Lear has to learn to survive in a world that is unknown to him at first by means of what the French scholar Michel De Certeau called "tactics" in his seminal study: The Practice of Everyday Life. In that book De Certeau identifies tactics - in opposition to "strategies," the tool of the elite—with the mechanism at hand for members of any society who live outside its boundaries: "[a]lthough they remain dependent upon the possibilities offered by circumstances, these transverse tactics do not obey the law of the place, for they are not defined or identified by it" (29). This explains why in the act of abandoning society and plunging in the woods, Lear must also change his vision of his kingdom: it no longer belongs to him so he has to resort to tactics traditionally linked with the "Other." These tactics are well-known by the Fool, whose seemingly meaningless and yet witty remarks serve Lear as a pastime and guide. The only tactics available to the old king are

\footnotetext{
${ }^{4}$ For a comprehensive study of the role of nature and in particular of the woods in Shakespearean drama, see Anne Barton, The Shakespearean Forest (New York: Cambridge University Press).
} 
paradoxically to join the Fool in his search for some sense in the world despite his initial fear of losing his mind: "O, let me not be mad, not mad, sweet heaven! / Keep me in temper. I would not be mad!" (Shakespeare, I.v. 45-46). In the end, Lear does learn this lesson and abandons himself to the tactics of the outcasts when the Fool asks him: "tell me whether a madman be a / gentleman or a yeoman" (III.vi. 9-10) and his royal interlocutor replies: "A king, a king!” (III.vi. 11). Through madness (the tool or tactic of the "Other" in King Lear) this monarch becomes familiar with the spaces in his land inhabited by the poor and the rejected. Andrew Bozio claims that in Shakespeare there is "a genealogy of the loss of place" (115) derived from the imprecise locations that reflects the changes in the Early Modern period.

The wall of the castle that formerly prevented any attack from the inhabitants from without stands as the physical boundary between rationality and madness. The symbolism of this wall is placed by Edward Bond at the core of his play with this fortress being a symbol of the Berlin Wall (Avădanei 72; Özmen100; Smith 73). In Bond we witness the rising of the wall which, as Lear claims he "built [...] to keep [his] enemies out" (3) thus building in so doing the very separation between spaces that reflects the struggle for power in this modern version. In his preface to this play Bond explains the structural genesis in Lear: "Act One shows a world dominated by myth. Act Two shows the clash between myth and reality, between superstitious men and the autonomous world. Act Three shows a resolution of this, in the world we prove real by dying in it" (xiv). Focusing on the specific spatial locations in this play we see that Act One opens "Near the wall" (1) and closes in the gravedigger's boy's house after the daughters' soldiers have broken into it, wreaking havoc in this shelter and raping his wife, Cordelia. Act Two opens in a courtroom where Bodice and Fontanelle have instructed the judge to incriminate their father, where Lear experiments "his own contemporary world of dream and nightmare, of purgatorial suffering" (Smith 76). This act also takes place in other settings: the cell where Lear is imprisoned and in a country road where "Lear and four prisoners chained together by the neck and blindfolded" (Bond 49), Lear's second cell is another location presented in this middle act.

The final space that Bond uses for his central act is an open field again (as with Act One), with Lear hurt and accompanied by the ghost of the gravedigger's boy. Finally, Act Three starts in a space that is already familiar to the audience (the gravedigger's boy's house) but this time it shows the ravages of time and the fights that have developed until then in that spot so that this old house is now: "[m]ore dilapidated, but obviously lived in" (68). The boy's ghost that first led and inspired Lear in his quest for reason in Bond becomes towards the end of the play an "increasingly spectral and parasitical figure of the gravedigger's boy [and 
his] debilitating and harmful emotions" (Smith 82) must be stopped with his second death to bring about Lear's death as a martyr. Nature appear in this version in Act III, scene iii several months later while Lear is walking with the ghost and he and Cordelia maintain a revealing conversation about the wall as a spatial landmark of power and corruption. The natural landscape in this scene offers the most ironic setting for the moral lesson that the once-powerful Lear delivers to Cordelia: "I didn't go out of my way to make trouble. [...] I've suffered so much, I made all the mistakes in the world and I pay for each of them. [...] Listen, Cordelia. You have two enemies, lies and the truth" (italics in the original; Bond 84). As Bloom argues Cordelia is, in Shakespeare: "Lear's own victim" (491) whose love and kindness Bond uses to turn her into the next tyrant after Lear and his daughters. The final image in this play is of the pervading wall with Lear's body falling from it after being shot dead.

If in Shakespeare the heaths are the space inhabited by the social outcasts, Bond takes that symbolism to the extreme. In Lear the space outside the wall is even more dangerous because we are remained of the abusive behavior of the ruler to force them to build the wall. From the gravedigger's boy's house in the countryside the power formerly represented by Lear and his monomaniac will to erect a wall are seen as a doom for the lower class, as the boy expresses: "[u]p and down, up and down. The king was mad. He took all the men from this village. But I hid. They'd worked with their hands all their lives but when they started on the wall their hands bled for a week" (Bond 25). Space outside the wall, Lear learns, is where the real world flourishes, not within its walls, as his daughters tried to persuade him of. The Fool in King Lear is replaced here with the ghost of a boy: a character who performs the role of spiritual and moral support for the dethroned hero (arguably anti-hero) and who introduces him into the space outside and the tactics required to cope with the strategies of the ruling elite.

This house embodies the time it lived through, its former dwellers and the massacre triggered by Lear's and Cordelia's obsession. The house is a bearer of the tactics of the working class against its oppressors throughout time. Bond draws on the image of the home as a safe place and transforms it into a space for moral and material regeneration. This is the value of this symbol in Lear: to offer a space of shelter for hard times and a promise of salvation and sanity and this is precisely the tactics operated by its inhabitants as a defense against the power of the ruling leader on duty. Bond creates a clear-cut spatial dichotomy: the wall and the world, or the ruler and the subjugated by means of the strategies of the governor or "actions which, thanks to the establishment of a place of power (the property of a proper) elaborate theoretical places (systems of totalizing discourses)" (De Certeau 38). As such, Lear learns about the wall only when he is outside and, 
subsequently, his discourse about his fortress mutates. Language and power are inextricably connected to the outcome of the spatial praxis and its articulation in a center (of power) and a periphery (here shown as the last remnants of the Promised Land in the boy's house and the woods).

The house in the woods inhabited by the boy and Cordelia represents the last Edenic natural landscape, a "temporary pastoral refuge" (Smith 75) or place where the forces of power could hardly enter. This sanctuary is eventually violated in favor of the corruption of Bodice and Fontanelle's troops. The bucolic venue of this country house is the perfect shelter for Lear to hide in his escape from his daughter's murderous attempts. Act Three opens in this setting allegorically presented as the promise of a better future for its new inhabitants: the couple of Thomas and Susan and their friend John so that in a way, this house stands as a time capsule where the love triangle Boy-Cordelia-Carpenter (a man from the village who was in love with her) is repeated. ${ }^{5}$ The similarities between the two stories imply a sort of temporal paralysis linked to this house in nature, as if the spatial coordinate had won over the temporal axis showing a house that resists the passing of time. In his study about spaces entitled: “Of Other Spaces: Utopias and Heterotopias" the poststructuralist scholar Michel Foucault explores heterotopias as those spaces outside the societal norms. Foucault examines the temporal dimension associated to some of those spaces in his theory about heterochronies. The boy's house and the natural scenery that surround it correspond to the "heterotopias linked to time in its more futile, transitory and precarious aspects, a time viewed as celebration. These then are heterotopias without a bias toward the eternal. They are absolutely time-bound" (Foucault 335).

Time also helps to bring about the actions in Feinstein's Lear's Daughters in evoking the past and bringing it forth on stage. Feinstein's feminist prequel of King Lear features the three daughters of an impassive king, their nurse and the Fool, who also assumes the role of narrator, all of them played by women, in line with the tenets of the WTG. In her article: “Lear's Daughters, Adaptation, and the Calculation of Worth" professor Stephannie S. Gearhart notes what she calls an "antigenealogy" (n.p.) in Feinstein's play as regards the temporal setting of the story and its condition of prequel to Shakespeare's classic. Gearhart connects the spatiotemporal structure of this play to the structure of the rhizome as described by the poststructuralist scholars Gilles Deleuze and Félix Guattari. Lear's

\footnotetext{
${ }^{5}$ On the basis of this interpersonal relations, we could find further "family" ties around Lear; for instance, in King Lear where Bloom identifies the trio Lear-Cordelia-Fool as "the play's true family, its community of love" (494) being this another fallen-from-grace "family" united more for their role of outcasts than for their actual understanding of reality around them (in the king's case).
} 
Daughters starts with the Fool introducing the characters to the audience in the manner of a troubadour or an off-stage narrator mentioning Lear in the first place and then his daughters and in the third place the Queen, absent in Shakespeare's play.

Lear's Daughters plays a game of temporal and spatial mirrors: the audience is certainly familiar with Shakespeare's version and yet Feinstein has the Fool introduce this play in a retrospective manner in spite of being the prequel to Shakespeare's play: "There was an old man called Lear, whose daughters, da da da da, fear, the Queen was their mum" (Feinstein 217). With the Fool assuming the leading voice in this play, the power relations are reversed as regards gender in rapport with King Lear; nevertheless, the king's ubiquitous presence in this play is still dominant. If in Shakespeare the king exerted his power by calling on his military force and Bond's Lear showed his superiority by drawing on his eventual self-realization or anagnorisis, in Feinstein we come across a king whose power is not directly bound to space but is, precisely for this reason, even more powerfully performed on stage. As the character of Cordelia declares: "words are like stones, heavy and solid and every one different" (217) because it is words that endow the absent king (performed here by the Fool in disguise) with his power. Language is in fact the mightiest resource in Shakespeare. Cordelia's inability to verbalize her love for her father - which she sees as a "subtraction from her love of a husband," as Anthony David Nuttall expresses in: A New Mimesis: Shakespeare and the Representation of Reality (73) - make up for Lear's verbal impetus, who "succeeds in saying what no one else, not even Hamlet, ever could say" (Bloom 494).

The stage is empty of power in Lear's Daughters as the title anticipates, placing the focus on the three girls, two of whom are morally criticized in Shakespeare and demonized in Bond. Here they are not only part of the story of an arguably ousted king of Britain but they are the ones who give birth to it as they listen to "fairy-tales in the nursery" (Feinstein 218). Spaces in this place take the form of phantoms of a bygone past, only partly retrievable by the interrupted remembrances of the girls and the nurse. The house in Bond that sheltered Lear gathered the memories of its past inhabitants and somehow magically reenacted them in its new dwellers transforming that place in a heterochronie of lost time. Contrary to that use of space, which preserved and evoked other times, the castle and its only room where the actions develop in Feinstein's play is strong enough to build spaces and emulate times that the three girls long for. The past in Lear's Daughters correspond to "heterotopias of time which accumulate ad infinitum" (italics in the original; Foucault 355) because old events are performed through linguistic evocation so that the stage in this version comprises not only other times 
but also other spaces. The past is also evoked when the girls' nurse diverts them telling the stories of their birth. She relates each birth with a cosmic event in the manner of Medieval and Renaissance fateful historical landmarks of heroes and gods who come to the world. Thus, when Goneril was born "a comet rushed through the sky, leaving a red trail in the black" (Feinstein, 2000: 218) and with Regan "a volcano erupted" (218).

The actual references to the exterior of Lear's castle in Feinstein's play are scarce. In scene vi, the girls surround the Queen and start asking her questions frenetically from Regan's demand of her opinion about her own hair escalating to Cordelia's impertinent inquiry about her mother's death, which make that the queen "collapses to floor" (Feinstein 223). Among the several questions posed the dramatists purposefully include Regan's apparently innocent: "Can I go out?" (222) followed by Goneril's inquiry: "Why are we always shut in?" (222) and by these two daughters' question to the queen: "Do you ever go out?" (222). The reason for their mother's isolation from the outer world is due to a considerable extent to her poor health condition, which is only partially envisaged by the youngest princess, Cordelia while her sisters only wonder why they are not allowed to go out. The blurriness of the split time in Lear's Daughters between the past and the present is emphasized in the innocent comments of young Goneril, Regan and Cordelia and their present-time selves, more mature and aware of their relegated, secondary role as daughters to the king.

The sole trace of the outside they perceive in the present is the glance of the fragmented vision through a window on the wall, as they prefer to dive into their past than cope with the fact that they are isolated in their father's fortress. Thus, the younger version of the princesses does turn to strategies of power, in De Certeau's words, thanks to their lack of awareness of their condition, which Feinstein and the WTG undermine focusing attention on the girls and the events in their lives that turned them into the ingrate daughters depicted by Shakespeare and Bond. ${ }^{6}$ As children, the sisters were able to approach issues such as their mother's death on the basis of their age and even Goneril's sitting on the king's throne as she utters the overtly defiant statement as she does so: "he is angry because he knows what I am thinking and I smile on-because I want him to know" (220). In the previous stances the young princesses "produce, tabulate and impose [...] spaces" (De Certeau 30) using the strategies of the elite by virtue of

\footnotetext{
${ }^{6}$ Interestingly, though, Feinstein and the WTG have their princesses hold the royal crown (another symbol associated to the power) among the three in the closing scene of this play, a scene that Fischlin and Fortier interpret as "potential solidarity and the symbolic empowerment associated with grasping the crown" (216).
} 
their social stratus and the naivety of their age. The little space left for the girls in the present time both metaphorically and physically is symbolized in their confinement in the room where the story unfolds. The room and the window on stage are the spaces of the grown princesses, who admit sorrowfully that they are there to "marry and breed" (Feinstein 229) as "valuable merchandise" (229). Since that moment, they assume that they can no longer create spaces of power so they learn the tactics needed to survive, to "use, manipulate, and divert these spaces" (De Certeau 30) resulting in the vultures they become in the other two plays.

The princesses can only abandon the paternal space of power (i.e., the castle) with a marital contract, conveniently symbolized in the ledgers that Goneril shows to Regan proving that their value is embodied by the money they are worth to the eyes of their materialistic father (Feinstein 229). Curiously, the ledgers that Goneril hands out to Regan contains the worth of paternal love for each daughter in numerical cyphers, as Goneril nervously exclaims: "[t]hey say Regan, Second Daughter of Lear, is worth this much" (229). The ledger in Feinstein's version is an incredibly resourceful mechanism of power held by the king - thus a strategywhich forces his daughters to use tactics to tackle their father's will. According to Gearhart, the economic ideology at the backdrop of Feinstein's play holds a narrow connection with Thatcher's policies so the ledger adopts here multiple intratextual and socio-historical references (n.p.). There is no actual conversation between the girls and their father as we can find it in Shakespeare or Bond, yet this book clearly illustrates what Lefebvre called: "representation of space."

Lefebvre defines representation of space as a: "conceptualized space, the space of scientists, planners, urbanists, technocratic subdividers and social engineers, $[\ldots]$ - all of whom identify what is lived and what is perceived with what is conceived" (Lefebvre 38). Feinstein's Lear is depicted as a monarch whose only concern is his kingdom and his material goods, among which he counts his own daughters. In assigning a certain pecuniary value to his daughters, Lear is making use of his power as a monarch and a father to divide the space of his kingdom and ironically giving up in favor of his daughters and their husbands the same power he is enforcing for the last time. This game of power relations has its materialization in the ledger that operates as a symbol of paternal love and material goods at once. Lear's Daughters offers the family rationale leading up to Goneril and Regan's filial ingratitude overcome in the end of this play with a more optimistic view of the sisters' love for each other but, as Bloom regrets: "the only authentic love is between parents and children, yet the prime consequence of such love is only devastation" (483).

There is yet another symbol in Feinstein's revision of the last days in the life of this ancient monarch that shows how Lear controlled the life of his daughters 
and subjects: the bridge. It operates as the princesses' weak link with reality outside their gilded cage. In one of the stories the nanny makes up for the girls, she talks of Lear walking over the bridge in a messianic fashion evoking Biblical images:

Nurse. (...) The King walked over the water to meet us.

Cordelia. Over the water?

Goneril (to Cordelia). Over a bridge.

Nurse. Yes, that's better. Over a bridge. We had to build a bridge to get to him. The Queen crossed the bridge and everybody had to cheer.

Reagan. You were there.

Nurse. Was I? (pause) If you want me there.

Goneril. No. (slowly, concentrating. She moves to Nanny) Nanny stayed on this side of the bridge.

Nurse. That is my place. (curtsies to Goneril). (Feinstein 223)

The nurse and the girls alike engage in the creation of a mythical origin for an otherwise regular occasion of father-children meeting. Yet, by evoking a blend of the symbolism of Biblical figures and myth, ${ }^{7}$ Feinstein denounces the twofold structure of power exerted on the one hand by Lear-like a redeemer living in regions overseas - and the princesses - who assert: "Nanny stayed on this side of the bridge" (223). Both Lear and Goneril are subjects of power in the former scene, which accentuates the loss of Lear's power as he divides his kingdom and Goneril's suicide led by greed and desperation in Shakespeare. For this reason, the younger version of these princesses that appears did rely on strategies (such as creating their own spaces and vindicating their power) whereas the three adult princesses in Lear's Daughters must adapt to the spaces allocated for them with their tactics and abide by the power of a father who puts in numbers their worth on his ledger.

\footnotetext{
${ }^{7}$ As Phyllis Rackin claims Shakespeare focused more on the "tragic errors and sufferings of his protagonists and their metaphorical implication rather than on the ambiguities of historical process and the difficulties of historical representation" (30). Hence, in Lear's Daughters there is a combination of times and moments in the story of this ancient king when Shakespeare's own also blurs historical boundaries. Similarly, Nuttall notes that Coriolanus or Antony and Cleopatra often present anachronisms such as the presence of clocks at a time when they did not exist yet (100-01).
} 
The image of the sisters encased in a gilded cage in Lear's castle discussed above meets its continuation in Shakespeare's King Lear in the new dwellings of the two eldest sisters and their husbands Albany and Cornwall. Shakespeare's Regan exerts her newly acquired power as Cornwall's wife and the owner of half of the kingdom. In her words: "This house is little. The old man and 's people / Cannot be well bestowed" (Shakespeare, II.iv. 329-330). She then presents herself as the master of a house and it is now that she puts at work the strategies that ensure her the perpetuation of the power she holds. At this point her ill-natured soul indicates urges her to get rid of Lear's men if she wants to keep power. Regan and Goneril then decide to reduce his kinship, as his position as an outcast allows them to abuse their newly received power against their father.

In King Lear Regan's declaration of intentions against her father betrays her evil plans: "I dare avouch it, sir. What, fifty followers? / Is it not well? What should you need of more?" (II.iv. 272-273) which conveys the idea that power has been transferred to her and she is using the strategies of its very own structure to keep it. Yet, Lear's desperation has reached the extreme of "quantif[ying] his daughters' love, this time according to the number of followers each woman will allow him to retain in his retirement" as Gearhart puts it (n.p.). His daughters' attack on Lear is a condemn for a king who complains: "a king deprived of his kinship is "nothing""8 (Frye 109) which is why, once deprived of his land, the rest of his "goods" (i.e., his kinship) are also bound to disappear. He who controls a territory or any other space, also owns power and it is, normally, political power. Power, nonetheless, must be understood back in Shakespeare's day as something that could be seen, touched and passed on from one person to another, such as Lear's kingdom, the materialization of abstract space. Kott uses the metaphor of a "relentless struggle of living people who sit together at one table" (8) to speak of the pair: power-goods/land that existed in the early seventeenth century in England.

In Lear the transfer of the power staged in the space inhabited by the new rulers matches another curious manifestation of the poetics of power in the surgery trestle table in Bond. This space, which served alternative purposes, now translates as the torture room for Fontanelle, who falls victim of her and her sister's malicious scheming against their father. Act II, scene vi shows the dismemberment of Fontanelle's body and Bodice's death before the astonished gaze of a king who can barely recognize his own children and finally laments: "[s]he sleeps inside like

\footnotetext{
${ }^{8}$ The theme of "nothingness" is also connected to Cordelia's failure in verbalizing her love for her father. In this sense, Maria de Jesus Crespo Candeias Velez Relvas notes a paradoxical connection between absence (nothing) and plenitude, power as regards the sue of space, silence and power to add dramatic value to the scene (Crespo Candeias Velez Relvas 120).
} 
a lion and a lamb and a child. [...] If I had known this beauty and patience and care, how I would have loved her" (Bond 59). The torture table where Fontanelle's body rests showcases the new turn of power in this play, right before Cordelia seizes power. As this play shows, power is not connected indissolubly to a person, it is rather a condition or state of those who can control the space around them, which accounts for the different rulers that the symbol of power (the wall) has met: Lear, his daughters and, finally, Cordelia.

The two cells in which Lear is imprisoned in this story bear witness to a macro-structure of power that preys on the most vulnerable ones in any society. Prisons are, as Foucault agrees, one of the clearest heterotopias of deviation "occupied by individuals whose behavior deviates from the current average or standard" (Foucault 353). Lear committed the crime of relinquishing his power and he paid it with insanity first and the role of preacher later on, akin to the LearMessiah in Feinstein's own version. When Lear is in his second cell, his daughters' ghosts appear to him. Once more we encounter a preeminence of the temporal dimension at the expense of the spatial one, since the space of the prison momentarily abandons its somber air and adopts in turn a more joyful tone with the children asking their father to do their hair only to be replaced with Lear's mournful comment to Bodice's mother's dress: "you might as well have worn her shroud" (Bond 39) partly echoed by Feinstein's Regan who recalls childishly how their nurse would brush their hair (Feinstein 227). Not even in his evocations is Lear free from the ghost of his past, both metaphorical and real as he could actually see and talk to them. This is another major achievement of Bond: to delve into the psychology not of the girls (as in Feinstein and the WTG) but of the obscure Lear in his search for the poetics of power onstage.

\section{Conclusion: morphing space and regenerating power}

The two twentieth-century plays examined in this article add up to the literary and historical value of Shakespeare's King Lear, one of the most thrilling and somber stories of English drama. Contemporary readings of Lear's self-triggered dethroning owe to the poetic license rooted in the "cultural evolution" (Nuttall 167) of all stories, which regards the possibility to introduce new elements and enrich the original narrative or the main source with new interpretations from the culture that reads it (167). From the king's castle to the woods where Lear escapes, spaces in the three plays represent more than the mere geographical setting where action occurs. Sometimes the spatial location of certain plays universalizes the action and the characters. As this article demonstrates, this is especially true for the story of this king, whom Bloom referred to as: "the most sublime character" (1998: 493) so, when a piece of drama achieves what King Lear has reached, we 
are in front of a veridic "timeless mix of the primitive and the contemporary" as Bloom stated (65) in reference to Bond's Lear, the most known of Shakespeare's versions of this play. The proliferation of adaptations and versions of this play have not only eternalized the character of this abandoned king but also his story. In fact, Lear has become what he now is because he did not and still does not fit in a single category of human, he was "King, Father, Everyman, God-on-Earth; Daughter; Bastard; Loyal Servant; Madman; Traitor" (Oates 22) all in one. Or, in Bloom's words: "[e]ven if Shakespeare [...] is only a socially inscribed entity (...). Shakespeare is everyone and no one" (487-88) as happens with the domed king in these stories.

In summary, through the performative use of space made by Shakespeare his tragedy speaks of the cruelty of the exterior world and of the protagonist's need to adopt the "tactics" of survival of those who inhabit it. These spaces of power are taken to the extreme of theatrical performativity with the use of a genuinely dividing element onstage - the wall in the case of Bond's Lear. As discussed before, this wall is the visual performance of power per se onstage and it is upon trespassing its boundaries that its monomaniac constructor opens his eyes to the space beyond his fortress. Equally, interior spaces in Lear are treated as spaces of destruction and death, such as the surgery room where Bodice is dissected. But these spaces of misery leave also room for momentary hope exemplified by Lear's daughters' ghosts in his cell bringing forth the long-gone memories of better days altogether. Feinstein and the WTG further explore this trope in the prequel Lear's Daughters. There the raising of Lear's family unfolds in an enclosed space (the castle's parlor) with the three princesses invoking their earliest recollections of their absent father in a heterotopic space that comprises past, present and future spaces and times.

\section{WORKS CITED}

Avădanei, Dragos. "Bonded Shakespeare." Multicultural Representations. Literature and Discourse as Forms of Dialogue. Eds. Iulian Boldea and Cornel Sigmirean. Romania, 2016, pp. 69-76.

Barton, Anne. The Shakespearean Forest. Cambridge University Press, 2017. DOI: https://doi.org/10.1017/9781139015257

Bloom, Harold. Shakespeare. The Invention of the Human. Riverhead Books, 1998.

Bond, Edward. Lear. Hill and Wang, 1976. 
Bozio, Andrew. Thinking Through Place on the Early Modern English Stage. Oxford University Press, 2020. DOI: https://doi.org/10.1093/oso/9780198846567.001.0001

Certeau, Michel De. The Practice of Everyday Life. Translated by Steven Rendall, University of California Press, 1988.

Crespo Candeias Velez Relvas, Maria de Jesus. "Lear and Quijote, Two Wanderers On Uneven Paths." The Grove. Working Papers on English Studies, vol. 26, 2019, pp. 117-26. DOI: https://doi.org/10.17561/grove.v26.a7

Feinstein, Elaine, and The Women's Theatre Group. (2000). "Lear's Daughters" Adaptations of Shakespeare." Eds. Daniel Fischlin and Mark Fortier. Routledge, 2000, pp. 217-32.

Fischlin, Daniel, and Mark Fortier. Adaptations of Shakespeare: A Critical Anthology of Plays from the Seventeenth Century to the Present. Routledge, 2000.

Foucault, Michel. "Of Other Spaces: Utopias and Heterotopias." Rethinking Architecture. A Reader in Cultural Theory. Ed. Neil Leach. Routledge, 2005, pp. 330-36.

Frye, Northrop. Northrop Frye on Shakespeare. Ed. Robert Sadler. Yale University Press, 1986.

Gearhart, Stephanie S. "Lear's Daughters, Adaptation, and the Calculation of Worth." Borrowers and Lenders: The Journal of Shakespeare and Appropriation, vol. 7, no. 2, 2012, n.p.

Gillies, John. (2001). "The Scene of Cartography in King Lear." Literature, Mapping, and the Politics of Space in Early Modern Britain. Ed. Andrew Gordon and Bernhard Klein. Cambridge University Press, 2001, pp. 10937.

Knight, Wilson G. The Wheel of Fire. Meridian Books, 1964.

Kott, Jan. Shakespeare our Contemporary. Norton, 1974.

Lefebvre, Henri. The Production of Space. Translated by Donald NicholsonSmith, Blackwell, 1991.

Nuttall, Anthony David. A New Mimesis: Shakespeare and the Representation of Reality. Yale University Press, 2007.

Oates, Joyce Carol. "'Is This the Promised End?': The Tragedy of King Lear." The Journal of Aesthetics and Art Criticism, vol. 33, no. 1, 1974, pp. 1932. DOI: https://doi.org/10.1111/1540_6245.jaac33.1.0019 
Özmen, Özlem. Re-Writing Shakespeare in the Twentieth Century: Edward Bond's Lear, Arnold Wesker's The Merchant and Howard Barker's Gertrude-The Cry in Socio-Historical Context. Doctoral Dissertation. Hacettepe University, 2018.

Rackin, Phyllis. Stages of History: Shakespeare's English Chronicles. Cornell University Press, 1993.

Sewell, Arthur. "Tragedy and the 'Kingdom of Ends." Shakespeare: Modern Essays in Criticism. Ed. Leonard F. Dean. Oxford University Press, 1967, pp. 295-316.

Shakespeare, William. King Lear. Eds. Barbara A. Mowat and Paul Werstine. Washington Square Press, 2005.

Smith, Leslie. "Edward Bond's Lear.” Comparative Drama, vol. 13, no. 1, 1979, pp. 65-85. DOI: https://doi.org/10.1353/cdr.1979.0005

Turner, Henry S. "King Lear without the Heath.” Renaissance Drama, vol. 28, 1997, pp. 161-193. DOI: https://doi.org/10.1086/rd.28.41917339

Vizcaíno Macero, Candelaria. "Los Espacios Simbólicos en El Rey Lear de W. Shakespeare a través de la Adaptación Fílmica de A. Kurosawa en Ran." CAUCE Revista Internacional de Filología y su Didáctica, vol. 28, 2005, pp. 439-68.

Received February 72021

Revised version accepted December 102021 